\title{
An analysis of the use of badges in the SAPO Campus platform: the perspective of communities' administrators
}

\author{
Inês Araújo, Carlos Santos, Luís Pedro \\ \& João Batista
}

\begin{abstract}
:
SAPO Campus is a social media platform for educational contexts based on the basic principles of Web 2.0 and social networks. The platform has a badge feature that allows community members to engage in gamification dynamics by creating, supporting and assigning badges. An analysis of the platform interaction data shows that, despite some cases of success in the use of badges, the great majority of users never used this feature, especially teachers. In order to understand the reasons behind this lack of use, a questionnaire was administered to 61 administrators of communities in SAPO Campus. The overall results show us that this feature was not used because administrators thought it was hard to implement with their students, especially in what concerns its planning and use in an engaging way. In this article we analyze the general preferences indicated throughout the questionnaire regarding this functionality, in order to understand which changes should be implemented to improve its use.
\end{abstract}

Keywords:

badges; SAPO campus; gamification. 


\title{
Uma análise do uso de crachás na plataforma SAPO Campus: a perspetiva dos administradores das comunidades
}

\begin{abstract}
Resumo: O SAPO Campus é uma plataforma de natureza social para contextos educacionais baseada nos princípios básicos da Web 2.0 e redes sociais. A plataforma possui uma funcionalidade de crachás que permite que os membros da comunidade participem em dinâmicas de gamificação criando, apoiando e atribuindo crachás. Uma análise dos dados de interação da plataforma mostra que, apesar de alguns casos de sucesso no uso de crachás, a grande maioria dos utilizadores nunca utilizou esse recurso, principalmente os professores. Com o objetivo de compreender as razões subjacentes a essa falta de uso, um questionário foi aplicado a 61 administradores de comunidades no SAPO Campus. Os resultados gerais mostraram que esta funcionalidade não era usada porque os administradores achavam que era difícil implementar com os seus alunos, especialmente no que diz respeito ao seu planeamento e uso de maneira pedagogicamente sustentada. Neste artigo analisamos as preferências gerais indicadas no questionário sobre esta funcionalidade, com o objetivo de compreender que mudanças devem ser implementadas para melhorar os seus padrões de utilização.
\end{abstract}

Palavras-chave: crachás; SAPO campus; gamificação.

\section{Une analyse de l'utilisation des badges sur la plateforme SAPO Campus: le point de vue des administrateurs de la communauté}

Résumé: SAPO Campus est une plate-forme sociale pour les contextes éducatifs basés sur les bases du Web 2.0 et des réseaux sociaux. La plateforme possède une fonctionnalité de badge qui permet aux membres de la communauté de participer à la dynamique de la gamification en créant, en soutenant et en attribuant des badges. Une analyse des données d'interaction de la plate-forme a montré que, malgré certains cas d'utilisation réussie de badges, la grande majorité des utilisateurs n'ont jamais utilisé cette fonctionnalité, en particulier les enseignants. Afin de comprendre les raisons sous-jacentes à ce manque d'utilisation, un questionnaire a été appliqué à 61 administrateurs de la communauté dans SAPO Campus. Les résultats globaux ont montré que cette fonctionnalité n'était pas utilisée parce que les administrateurs estimaient qu'il était difficile à mettre en œuvre avec leurs élèves, en particulier en ce qui concerne leur planification et leur utilisation d'une manière pédagogique soutenue. Dans cet article, nous analysons les préférences générales indiquées dans le questionnaire à propos de cette fonctionnalité, afin de comprendre quels changements devraient être mis en œuvre pour améliorer leurs habitudes d'utilisation.

Mots-clés: badges; SAPO campus; gamification.

\section{Un análisis del uso de insignias en la plataforma SAPO Campus: la perspectiva de los administradores de las comunidades}

Resumen: SAPO Campus es una plataforma de naturaleza social para los contextos educativos basados en los principios básicos de la Web 2.0 y las redes sociales. La plataforma tiene una funcionalidad de insignias que permite a los miembros de una comunidad que se adhieren a la gamificación dinámica mediante la creación, la colocación y la asignación de insignias. En el análisis de + de intercambio de datos de la palatforma se muestra que, a pesar de algunos casos de éxito en el uso de insignias, una gran cantidad de usuarios nunca ha utilizado esta funcionalidad, especialmente profesores. Para comprender las razones que preceden a esta falta de uso, un cuestionario ha sido contestado por 61 administradores de comunidades en SAPO Campus. Los resultados revelan que no se utilizó porque los administradores creen que era difícil de implementar con sus estudiantes, especialmente en lo que respecta su planificación y utilización pedagógica. En este artículo se analizan las preferencias en cada una de las preguntas cuestionadas en relación con esta funcionalidad, para comprender qué cambios se deben implementar para mejorar su uso.

Palabras clave: insígnias; SAPO campus; gamificación. 


\section{Introduction}

The Internet enabled educational institutions to adopt technologies in order to improve, in different but complementary dimensions, their educational offerings. Learning Management Systems (LMS) emerged as one of the technological possibilities in this field and allowed the classroom to be spatial and temporally expanded, making it easier, for instance, for students to continue their educational activities at home. However, new challenges arose with Web 2.0 technologies. More than a technological breakthrough, the 2.0 movement extended the possibilities of using the Internet from a participative culture perspective, allowing users to adopt new behaviors of content consumption and creation. The proliferation of publications on websites and blogs, the creation and sharing of images and videos, and the rise of different social networks created new possibilities and challenges for educational institutions. These new possibilities and challenges triggered the appearance of new trends such as MOOCs (Massive Open Online Courses), where learning activities break down the walls of the classroom, allowing anyone, anywhere in the world, to be able to learn without the need for a formal and permanent enrollment with the promoting educational institution.

SAPO Campus was created in this overarching context and was initially designed to be used in higher education scenarios before a more generic platform was made available for institutions of all education levels (Santos, 2016).

However, these technological, educational and attitudinal evolutions also raised new questions. In the past decade, one of the most important questions was related to the certification of learning actions that may occur outside the formal and administrative umbrella of educational institutions. The Mozilla Open Badges initiative was created to answer this question, allowing to gather, on the same platform, badges assigned to each user in different learning contexts (Goligoski, 2012). From a technological standpoint, this feature was promptly supported by different LMS. SAPO Campus also implemented this feature, but not for the sole purpose of certifying skills. In SAPO Campus the main idea was always to explore the motivational and social potential of this feature (Santos, 2016).

Digital badges can be defined as images or symbols that depict the acquisition/ development of knowledge, skills or competences. The literature that explores the use of badges in educational contexts reveals that they typically have been used either as an assessment tool, a skill/competence recognition tool and/or a communication and motivation tool (Elkordy, 2012; Barey et al., 2012). Badges are expected to work by themselves as a motivational factor, however this is not usually a simple task. In a longitudinal study, Hanus and Fox (2015) concluded that the use of badges as a reward in compulsory activities inversely influenced learners' motivation. On the other hand, Hamari (2017) stresses that clear goals and immediate feedback, like it is possible to 
find in badges, have positive effects on the implementation of learning tasks. Another important point is the role that badges can play after being issued, such as the role of social marker within a community. By being visible, members see their work recognised and may influence their peers to work in order to receive the same badge (Gee, 2003; Hamari, 2017).

The effects of badges on motivation are not consensual and many authors warn that, when focusing only on extrinsic motivation, the use of rewards such as badges may have quick effects in short term periods but that these effects may dissipate in the Iong term (Burke, 2014; Chou, 2015; Kapp, 2012; Zichermann \& Linder, 2013).

Whichever is our position in this matter, trying to improve learners' motivation through the use of badges or other social recognition marker is an important issue in today's education. It is also important to find the reasons that prevent teachers from using this tool, which is often available on platforms they regularly use (Moodle, Edmodo and SAPO Campus).

This paper presents the results of a study carried out with the users of the SAPO Campus platform where it was intended to understand the reasons for the adoption of gamification strategies and, very specifically, the reasons why the badge feature in the platform was or was not used.

\section{The SAPO Campus Platform}

\section{Overview}

Since its initial design and launch in 2009, SAPO Campus aimed to facilitate the creation of an online space where educational institutions could interact with their students and provide them technological tools that they can use in their daily lives, a perspective that was significantly different from the one that was followed at the time by educational technology providers.

This perspective required a more flexible role from educational institutions because the dilution of hierarchies and privileges among all its members implemented in the platform creates conditions for the community to continuously adapt itself to the needs and interests of the overall community. One of the other recognised advantages that the SAPO Campus platform promotes is to bring together formal and informal learning communities in the same service (Santos, 2016). By doing so, it facilitates a Lifelong Learning relationship between the institution and its members, since membership does not depend on the official relationship with the institution and can be maintained indefinitely. This hopefully leads to a continuous relationship between educational institutions and its former students, maximizing the possibilities of joint partnerships between the market and the academy. Currently, SAPO Campus has several infocommunicational features such as: sharing features (files, links, images and videos), blog posting, chat 
service, task scheduling and the issuing of badges. All these features were implemented as SAPO Campus was evolving through the years. A new version of the platform is currently under development aiming to renew and optimise the services already available. It is within this context that the use given by the members to the different features was evaluated, showing that the badges tool stood out in a negative way.

Although this feature was available since 2013, until March of 2017 only 6.6\% of the existing communities had issued badges, and 1054 (44.8\%) out of the 2353 badges were assigned within a single community (Araújo, Santos, Pedro, \& Batista, 2017a). This is a very small percentage which led us to consider the need to invest in improvements. That is why we applied a questionnaire to the platform's users that aimed to gather evidences of the main difficulties they experienced with this tool as well as to understand potential features that could be added in order to increase its use.

\section{Badges in SAPO Campus}

In the SAPO Campus platform it is possible to make available badges that are, by default, managed by a community administrator. These badges essentially correspond to functions within the community (teacher, student, parent or guardian ...). It is also possible to create new badges for a community that are not connected with formal roles in the institution. Those badges can only be issued by the administrator of that particular digital space and are added to the member's profile. It is assumed that the function of administrator of a community is performed by someone who has the necessary maturity to manage and issue badges in the best possible way (Santos, 2016).

However, learning communities typically evolve reflecting the learning interests and needs of its members, allowing, for instance, that in a given moment in time someone can be an apprentice in one theme and simultaneously a teacher in other (Gray, 2004). In this line of thought, SAPO Campus facilitates the continuous reorganization of the learning community according to the needs expressed by its members in each moment. It is then natural that smaller communities (groups) may be created by teachers or other community leaders and that, over time, the remaining members may also organise themselves into other groups that share common interests or objectives in that community.

Within each group there is at least one member who assumes the administrator role. Only those who have an administrator role have access to the badges' creation tool and are allowed to issue badges to other members of that group. Every time a badge is issued, the receiving member has the right to refuse it, to accept it in private mode or to accept it in public mode. The way the member chooses to accept the badge indicates if the badge is visible in the user's profile only for other members of the group in which it was issued (private) or for the entire community (public). This possibility facilitates the self-preservation of members against badges that may be harmful to 
them, such as in situations of bullying among students (Santos, 2016; Santos, Pedro, Almeida, \& Aresta, 2013).

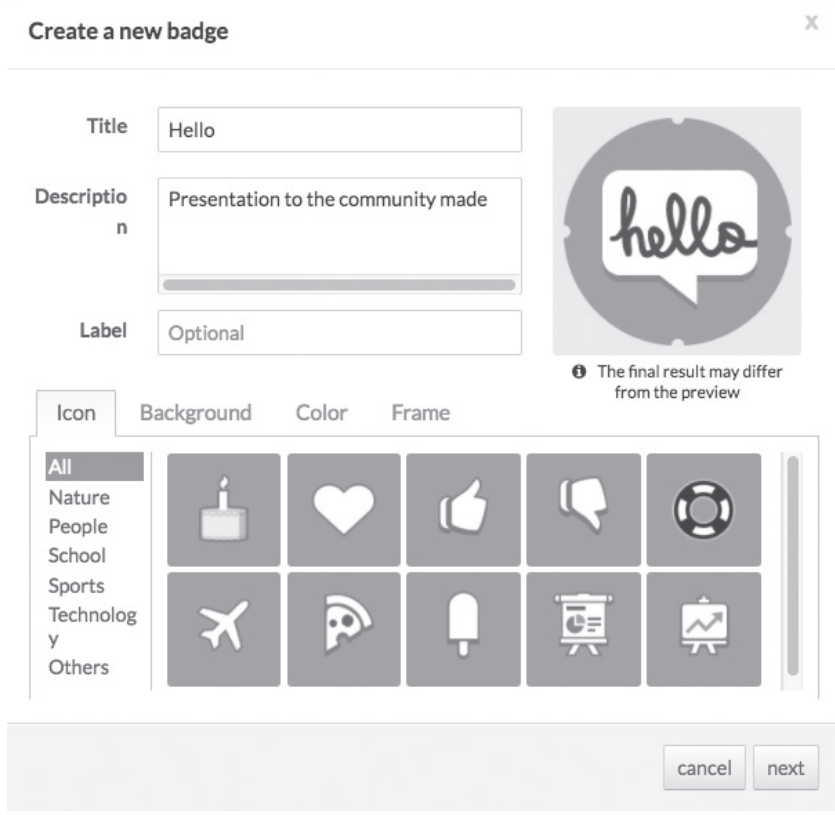

Figure 1. Badge creation tool

To create a badge, it is necessary to define its name and include a description that should indicate the reason or meaning of the symbol that will be issued, thus allowing the viewer to perceive what needs to be done by to be eligible to receive it. There is an optional label that overlaps the badge image. At the bottom there is an area with the graphic elements of the badge (icon, design background, color and frame). In total there are 126 icons available and organised by categories. There are also 9 design backgrounds, 18 colors and 6 frames available to choose from (see Figure 1). In this tool there is no way to upload an image. This decision was made by the product and design teams so the graphic identity of badges in SAPO Campus could be preserved. Other tools that offer open badges (eg https://www.openbadgeacademy.com) also tend to maintain the visual identity of the badge, since the value of a badge is always evaluated by the image it presents, "how professional/appropriate it is" (Jovanovic \& Devedzic, 2014, p. 61).

In SAPO Campus every member of a community may also endorse/recommend the issuing of badges. It is possible to perform this action directly on the published posts in the platform or with the badges available in any group or community. This endorsement/recommendation can be made even after a member has received a badge, 
consequently giving that member a strong recognition message. This fact remains visible in the context of the issued badge, being possible to see the accepted badges, the content the badge is associated with, but also the number of endorsements it has received from other members.

This tool was developed in close collaboration between the development team and the schools that participated in a SAPO Campus platform study. Many of the decisions took into consideration relevant suggestions and problems raised by the users involved in that study (Santos, 2016).

\section{Method}

\section{Data collection}

A survey was implemented through an online questionnaire tool intending to find the reason that lead to a low level of use of badges provided by the SAPO Campus platform. The administrators of communities and groups in the platform were asked to answer the survey.

The questionnaire had 4 parts:

- Personal information: participants were asked to answer questions about their age, sex, professional position, the academic cycle in which they are enrolled and their availability to be contacted in a later moment;

- Badge definition and translation: respondents were asked about the better Portuguese word for the concept of "Badge";

- Use of badges: participants were asked about who within a community should have permissions to issue and endorse/recommend badges, and what types of uses they intended to give to badges;

- Experience with the Badges' tool: participants were asked about their level of use of the badges' tool, examples of badges already created, but also suggestions of features to be included in the tool and reasons that may encourage the use of badges.

In order to reach a specific group of people, namely administrators of groups and communities in SAPO Campus, the questionnaire was disseminated by email. A total of 982 email messages were sent in two moments: during the first half of November 2016 and later, in January 2017. A total of 63 valid responses were collected, corresponding to $6.4 \%$ out of the total administrators with valid email messages.

\section{Results}

There was a slight female majority (54.0\%) in the sample and the vast majority $(87.3 \%)$ of participants were between 31 and 60 years old, being the age range from 41 to 50 years old the most frequent (38.1\%) (Figure 2). 


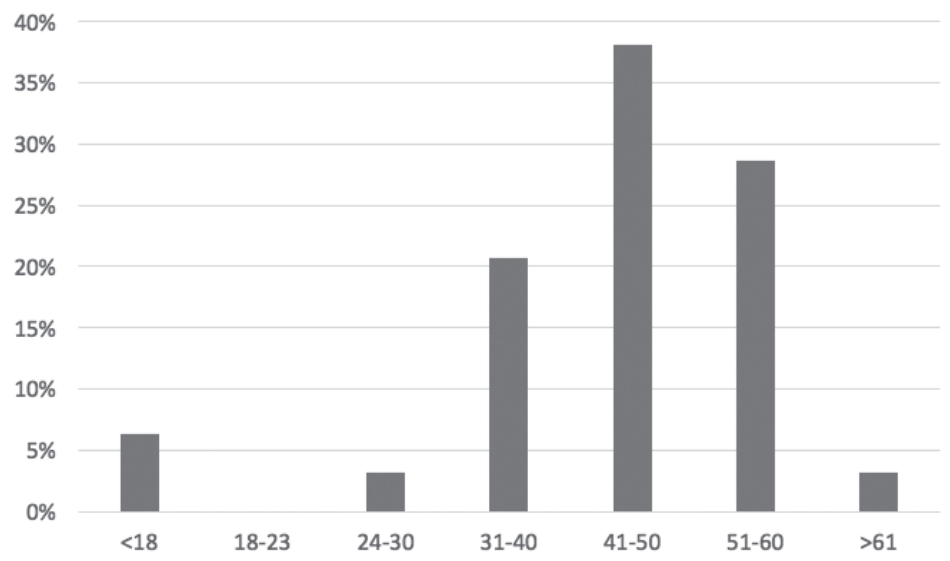

Figure 2. Sample's distribution, by age $(\mathrm{N}=63)$

The vast majority $(88.9 \%)$ of the participants performed the roles of teacher or trainer in the platform. The figure 3 presents their distribution by educational level (cycle in Portuguese).

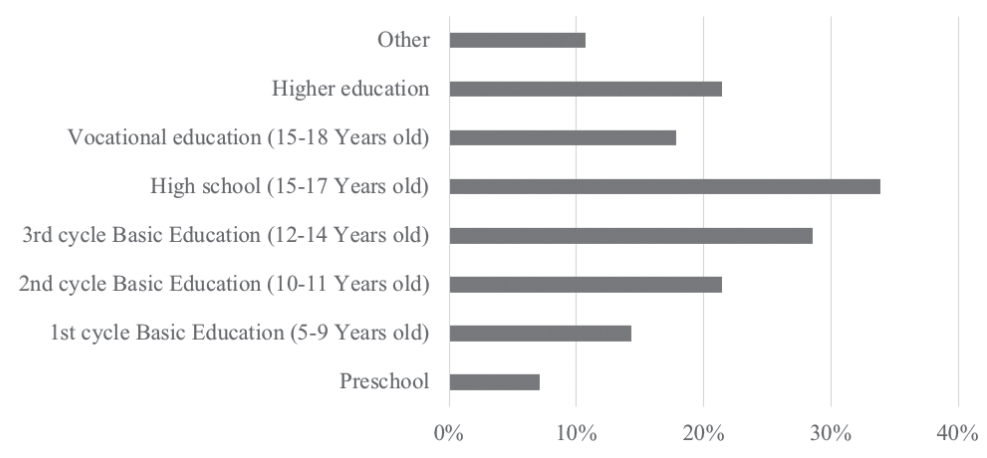

Figure 3. Sample's distribution, by education cycle $(N=56)$

About one-third of the teachers work in more than one academic cycle ( $n=16$, $28.6 \%$ ), with secondary education being the cycle with more teachers ( $n=19,33.9 \%$ ).

Regarding the use made of the badges' tool, 49.2\% ( $n=31)$ participants already used and knew the badge tool and $50.8 \%(n=32)$ had not used the tool in the date of response to the questionnaire (Figure 4). 


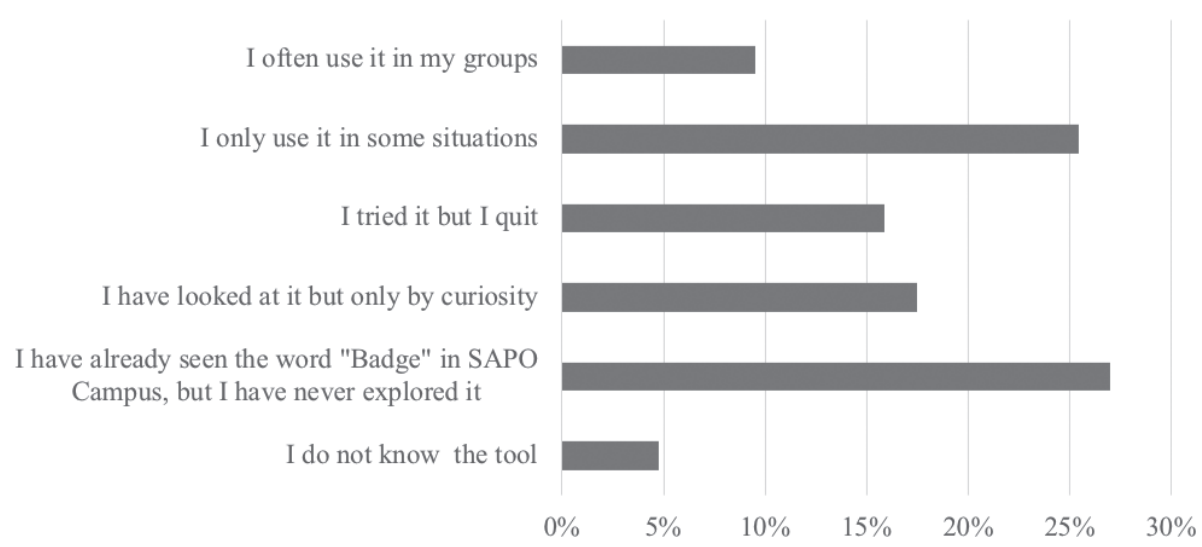

Figure 4 . Level of use of the badges tool $(N=63)$

The graph analysis (Figure 4) shows that only $4.8 \%$ of the participants did not notice that the SAPO Campus platform had a badges' tool, which indicates that the tool is visible to the vast majority of managers. Another relevant fact is that $27.0 \%$ saw that there was a badge button but never felt the will or curiosity to check what this tool was about. It suggests that they were indifferent to the badge concept, most probably because it is something associated with games and fun, something that is still seldom used in educational contexts. Also, 25.4\% answered that they use the tool in specific situations and $9.5 \%$ use it frequently, which means that there is a regular use by $34.9 \%$ of the respondents.

Regarding other options, $15.9 \%$ of respondents answered they have used the badges' tool but have meanwhile given up. The reasons that lead to this withdrawal are mainly related to the necessary time to plan its proper use (44.4\%). However, respondents also pointed out causes like the relevance of this activity to the group, being considered childish or even the group's lack of interest in badges. All of these reasons end up emphasizing the need to properly plan the badges' use, so that their creation and management are in accordance with the interests and importance of the strategy felt within the group.

Data also shows that it is necessary to analyse specific aspects of the badgs'e tool use. The first question asked was about the best Portuguese word to express the badge concept (Figure 5). It should be noted that the Portuguese translation presents several different possibilities (Araújo, et al., 2018). 


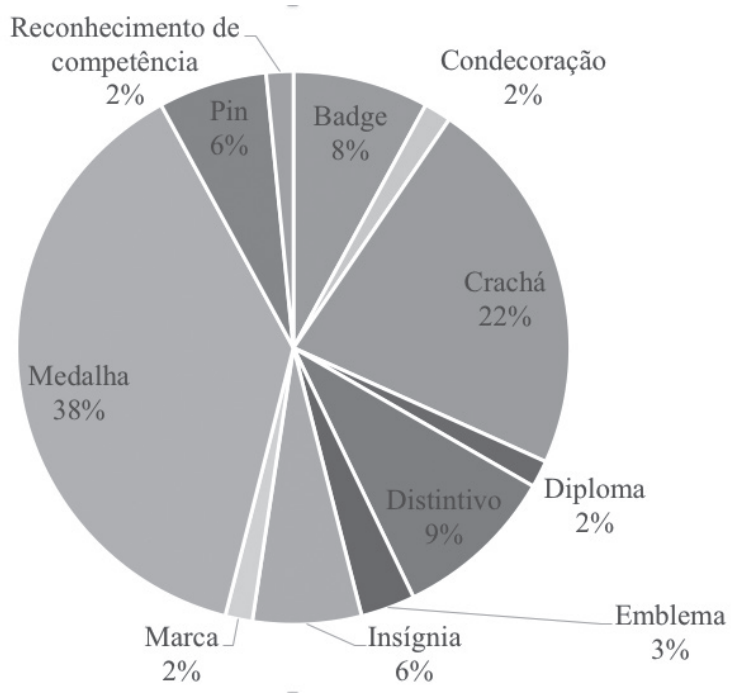

Figure 5. Distribution of answers about the best option to translate the badge word into Portuguese $(N=63)$

Figure 5 shows that the "Medalha" (Medal) option is the more frequently chosen. However, this term is associated with the idea of competition that does not apply to most situations in which badges are attributed (Halavais, 2012). This is a discussion that should be carried out as a group to reflect on the implications of choosing each of the terms in Portuguese. As another option, there is also the possibility of keeping the feature name in English.

With the second question we pretended to know which permissions each of the members of a community should have in the badges' tool. Respondents were asked to select one out of four possibilities (Figure 6).

Automatic Assignment Configured by Administrator

The principal of the school or the authority in the learning community

The teacher or authority in the group

The members of the group

The creator of the badge

The group administrator

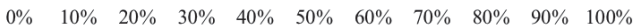

$\square$ Neither assign nor endorse/recommend $\square$ Only endorse/recommend the assignment $\square$ Issuing only in specific contexts $\square$ Always

Figure 6. Permissions each type of SAPO Campus' members should have in the Badge tool $(\mathrm{N}=63)$ 
The first result that stands out is a clear division over the automatic attribution of badges: for $27.0 \%$ of the respondents this can be done in all situations (always); and $27.0 \%$ consider they should only be able to endorse/recommend; $23.8 \%$ consider there should be no automatic assignment of badges; and $22.2 \%$ consider that automatic assignment can be done in specific contexts. This means that $76.2 \%$ agree that this feature should be implemented in the SAPO Campus platform but are still divided on the exact permissions of users when using this feature.

Another results that stands out is the difference of responses related to permissions between the Administrator of the group and the creator of the badge; and between the authorities of the group and the community. A majority of $52.4 \%$ of the respondents consider that the administrator should always have total permission of assignment and recommendation of badges, but that is an opinion that is not shared by the remaining respondents. Values range from $28.6 \%$ for group authorities to $23.8 \%$ for both creator and community authorities. For $39.7 \%$ of the respondents, the member that creates badges should only be able to endorse/recommend them to other members, and $52.4 \%$ consider that the authority in the group should be able to assign them but only in specific contexts. Finally, 30.2\% also think the same permission applies to the authority in the community. Another interesting finding is that for $60.3 \%$ of the respondents, members should only be allowed to endorse/recommend badges, something that already happens in the SAPO Campus platform. However, 22.2\% consider that they should be able to assign badges in specific contexts and $9.5 \%$ that they should always have full permissions.

The possibility of allowing members to import and use a repository of badges on their group, and also to reuse their content by editing it, is something that some other platforms allow (Edmodo and Moodle). However, this is not a feature available in the current version of SAPO Campus (Araújo, Santos, Pedro, \& Batista, 2017b) and a question was included in the questionnaire on order to understand if members were available to share badges created by them with other administrators. Data shows that $92.1 \%$ of the respondents were available to share their badges so they could be reused and adapted by other administrators.

Finally, an open-ended question asked respondents about the difficulties experienced in using the badges creation and assignment tool (figure 7). This question was asked just for those who actually used it $(N=30)$. 


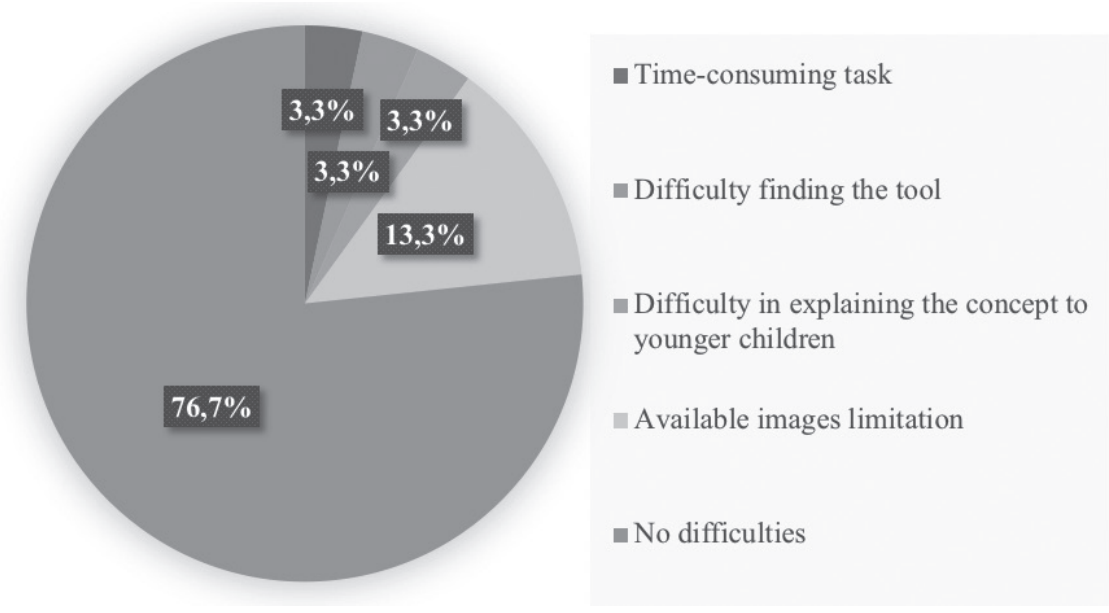

Figure 7. Distribution of difficulty types felt with badge tool $(\mathrm{N}=30)$

Figure 7 highlights the difficulties experienced by those who have already used the badges' tool in SAPO Campus. It should be stressed that the majority (76.7\%) of respondents not identified any problems. The most frequently mentioned difficulty is the limitation of the images available in the tool, since the provided library has only 126 images and it is not possible to add new ones. The remaining difficulties should not be overlooked, although they were only mentioned by a single person.

These results are important to the analysis and decision making related to the modifications that will be implemented in the new version of Badges' tool in the platform.

\section{Discussion}

After the analysis of the responses to the questionnaire we were able to understand that the main problem concerning the use of this particular feature is not related to the badge tool itself but with the very concept of badge. In fact, half of the respondents does not interact with the tool despite knowing it exists; and from those who use it, only a few use it frequently. Some respondents claim to have given up using the feature because it requires a lot of time to plan properly, although some situations in which the group did not react as expected were also detected.

“(...) anyone who ventures in building a non-trivial badge system will probably face a huge badge conceptualization problem: what are the achievements in a specific case, what to badge/reward, under what conditions, and, most importantly, how to chain and prioritize the achievements?" (Jovanovic \& Devedzic, 2015, p. 120) 
Since badges are something new and are not part of the teachers' usual resources, it is expected that without knowing any previous examples it will be difficult for them to understand how they can make the best use of it. This problem, also highlighted by Jovanovic \& Devedzic (2015), resulted in the creation of a MOOC entitled "Badges: how to use?" (Araújo et al., 2018, 2017a) and in the creation of a public blog with articles that present examples of badges that can be created and strategies that can be put in place, based on the examples created by the trainees who attended the MOOC (http:// campus.sapo.pt/blog/crachassugestoesexemplos).

It should also be stressed that "[e]stablishing the credibility of digital badges and ensuring that the various stakeholders value them is also important" (Dowling-Hetherington \& Glowatz, 2017, p. 8). The value of badges depends largely on previous experiences and credibility within the community in which they are used (Halavais, 2012). There is, therefore, a long way to walk, which is not only related with more knowledge of the tools available to create badges and how they work but especially with a clearer understanding of the concept and its possibilities in different learning scenarios.

However, the tool must meet the needs of the users. By analyzing the answers we noticed that there are some possible changes that can improve its use, such as: decreasing the steps to access the badges creation and management tool; enabling the upload of new images, as other tools do (www.openbadgeacademy.com), but without losing the graphic identity of the platform; enabling new design shapes by adding new frames; allowing the sharing of badges that can be reused in other situations; and implementing the automatic endorsement/recommendation and attribution of badges.

\section{Future Work}

It is important to disseminate examples of good practices so that other teachers and professionals can also try to implement them in their own contexts. One of the interesting issues verified during the MOOC "Badges how to use?" was the fact that teachers who shared their examples recognised the positive impact on their students and the many issues that arose because other teachers were also interested in adapting this strategy in their own contexts (Araújo, et al., 2017a). It is therefore important to find a mechanism that allows sharing examples and good practices of the use of badges among SAPO Campus members.

For this some of the members who participated in the MOOC will be invited to join a discussion group about the new features to be implemented. This feedback will be crucial to match the platform's features to the real needs of its users.

Finally, it is also important to proceed with studies related to the democratization of badges' creation and assignment. The limited role that regular users have when they interact with badges in the platform should be questioned and new privileges should 
be tested, in which any member of the platform will be able to create a badge or make a proposal for a new badge.

Being studied, these questions could lead to a renewed approach to the way teachers and students identify roles and responsibilities in educational contexts. We believe that this type of change is not possible to evaluate and implement through surveys with users that, probably, cannot imagine the consequences of this very different approach to teaching and learning.

\section{Acknowledgements}

This research Project is funded by national funds through FCT - Fundação para a Ciência e a Tecnologia, I.P., within the project "GamiLearning - Digital Games for Mediatic and Informational Literacy” (UTAP-ICDT/IVC-ESCT/0020/2014).

\section{References}

Araújo, I., Pedro, L., Santos, C., \& Batista, J. (2018). Crachás: como usar em contexto educativo? In M. J. Gomes, A. J. Osório, \& A. L. Valente (Eds.), Challenges 2017: Aprender nas Nuvens, Learning in the Clouds (2a edição, pp. 159-176). Braga: Centro de Competência em Tecnologias de Informação e Comunicação na Educação (CCTIC-IEUM). http://hdl.handle.net/10773/21672

Araúijo, I., Santos, C., Pedro, L., \& Batista, J. (2017a). Badges: How to use?: Training teachers trought a MOOC. In M. J. Silva, C. Ponte, \& J. M. Dodero (Eds.), 2017 International Symposium on Computers in Education (SIIE) (pp. 1-6). Lisbon: IEEE. https://doi.org/10.1109/SIIE.2017.8259667

Araújo, I., Santos, C., Pedro, L., \& Batista, J. (2017b). Digital badges on education: past, present and future. In A. Skarzauskiené \& N. Gudeliené (Eds.), Proceedings of the 4th European Conference on Social Media (ECSM) (pp. 27-35). Vilnius, Lithuania: Mykolas Romeris University. http://hdl.handle. net/10773/21671

Barey, J. et al. (2012, June 25). Six ways to look at badging systems designed for learning. Global kids Online Leadership Program [Blog post]. Retrieved from: http://www.olpglobalkids.org/content/sixways-look-badging-systems-designed-learning

Burke, B. (2014). GAMIFY: How Gamification Motivates People to do Extraordinary Things. EUA: Gartner, Inc.

Chou, Y. (2015). Actionable Gamification: Beyond Points, Badges, and Leaderboards. Octalysis Media.

Dowling-Hetherington, L., \& Glowatz, M. (2017). The Usefulness of Digital Badges in Higher Education: Exploring the Students' Perspectives. Irish Journal of Academic Practice, 6(1). https://arrow.dit.ie/ ijap/vol6/iss $1 / 1$

Elkordy, A. (2012, June 25). The future is now: unpacking digital badging and micro-credentialing for $\mathrm{K}-20$ educators [Blog post]. Retrieved from: https://www.hastac.org/blogs/angela-elkordy/2012/10/24/ future-now-unpacking-digital-badging-and-micro-credentialing-k-20

Gee, J. P. (2003). What Video Games have to teach us about learning and literacy. EUA: Palgrave Macmillan. 
Goligoski, E. (2012). Motivating the Learner: Mozilla's Open Badges Program. Access to Knowledge, 4(1), 1-8. http://ojs.stanford.edu/ojs/index.php/a2k/article/view/381

Gray, B. (2004). Informal Learning in an Online Community of Practice. The Journal of Distance Education / Revue de l'Éducation À Distance, 19(1), 20-35. http://www.synergiescanada.org/fr/journals/ synpra/jde/16/103

Halavais, A. M. C. (2012). A Genealogy of Badges: Inherited meaning and monstrous moral hybrids. Information, Communication \& Society, 15(3), 354-373. https://doi.org/10.1080/136911 8X.2011.641992

Hamari, J. (2017). Do badges increase user activity ? A field experiment on the effects of gamification. Computers in Human Behavior, 71, 469-478. https://doi.org/10.1016/j.chb.2015.03.036

Hanus, M. D., \& Fox, J. (2015). Assessing the effects of gamification in the classroom: A longitudinal study on intrinsic motivation, social comparison, satisfaction, effort, and academic performance. Computers and Education, 80, 152-161. https://doi.org/10.1016/j.compedu.2014.08.019

Jovanovic, J., \& Devedzic, V. (2014). Open Badges: Challenges and Opportunities. In E. Popescu, R. W. H. Lau, K. Pata, H. Leung, \& M. Laanpere (Eds.), Advances in Web-Based Learning - ICWL 2014. ICWL 2014. Lecture Notes in Computer Science, vol 8613 (pp. 56-65). Springer International Publishing. https://doi.org/10.1007/978-3-319-09635-3_6

Jovanovic, J., \& Devedzic, V. (2015). Open Badges: Novel Means to Motivate, Scaffold and Recognize Learning. Technology, Knowledge and Learning, 20(1), 115-122. https://doi.org/10.1007/s10758014-9232-6

Kapp, K. M. (2012). The Gamification of Learning and Instruction: Game-based methods and strategies for training and education. San Francisco: Pfeiffer.

Santos, C. M. N. (2016). Estudo, concepção e desenvolvimento de uma plataforma integrada de serviços web 2.0 para utilização em contexto de ensino superior. Universidade de Aveiro. Retrieved from http://ria.ua.pt/handle/10773/18603

Santos, C., Pedro, L., Almeida, S., \& Aresta, M. (2013). Decentralized badges in educational contexts: the integration of open badges in sapo campus. eLearning Papers, 35(November), 1-6. http:// openeducationeuropa.eu/en/article/Decentralized-badges-in-educational-contexts\%3A-theintegration-of-Open-Badges-in-SAPO-Campus?paper=133343

Santos, C., Pedro, L., Ramos, F., \& Moreira, A. (2011). Sapo Campus: what users really think about an institutionally supported PLE. http://journal.webscience.org/565/

Zichermann, G., \& Linder, J. (2013). The Gamification Revolution: how leaders leverage game mechanics to crush the competition. EUA: Mc Graw Hill Education.

Inês Araújo

Bolseira de Investigação no âmbito do projeto GamiLearning (http:// gamilearning.ulusofona.pt/pt/)

Universidade de Aveiro, Aveiro, Portugal Email: inesaraujo@ua.pt / inesjgc@gmail.com ORCID: https://orcid.org/0000-0003-0936-1411 
Carlos Santos

DigiMedia, DECA, Universidade de Aveiro, Aveiro, Portugal

Email: carlossantos@ua.pt

ORCID: https://orcid.org/0000-0003-0961-8088

Luís Pedro

DigiMedia, DECA, Universidade de Aveiro, Aveiro, Portugal

Email: Ipedro@ua.pt

ORCID: https://orcid.org/0000-0003-1763-8433

João Batista

DigiMedia, ISCA, Universidade de Aveiro, Aveiro, Portugal

Email: joao.batista@ua.pt ORCID: http://orcid.org/0000-0002-5872-5341

Correspondência:

Luís Pedro

Departamento de Comunicação e Arte

Campus Universitário de Santiago

Universidade de Aveiro

3810-193 Aveiro

Data de submissão: Março 2018

Data de avaliação: Junho 2018

Data de publicação: Setembro 2018 